\title{
DAMPAK ROTASI KERJA PADA MOTIVASI DAN KINERJA KARYAWAN HOTEL DI JEMBER
}

\author{
Faozen \\ Prodi Perhotelan, FISIP Universitas Muhammadiyah Jember \\ J1. Karimata No.49 Jember Kode Pos 69121 \\ faozen@akparmuhjember.ac.id
}

\begin{abstract}
This study entitlesthe 'Impact of Job Rotation at the Hotel Employee Motivation and Performance In Jember. This study is conducted to determine the impact of job rotation on the motivation and performance of employees in Jember. The study population is the tourists who visit by the total sample of 50 people.The determination of sample with nonprobability sampling method to form a saturated sample. Data collecting techniques in this study uses the method of observation, structured interviews, literature study and questionnaire.Data are analyzed by using multiple linear regression test stratified by path analysis. Based on the analysis of data and a description of the discussion indicate that the variable job rotation has a positive and significant impact on work motivation while job rotation on the performance of employees have a positive impact although not significant.Job rotation has a positive and significant impact on the performance of employees through work motivation.
\end{abstract}

Keywords: Job Rotation, Work Motivation, Employee Performance

\section{ABSTRAK}

Penelitian ini berjudul Dampak Rotasi Kerja Pada Motivasi Dan Kinerja Karyawan Hotel Di Jember. Penelitian ini dilakukan untuk mengetahui dampak rotasi kerja pada motivasi dan kinerja karyawan hotel di Jember. Populasi penelitian ini adalah para wisatawan yang berkunjung dengan sampel sebanyak 50 orang, penetapan sampel dengan metode nonprobability sampling dengan bentuk sampel jenuh.Teknik pengumpulan data dalam penelitian ini menggunakan metode observasi, wawancara berstruktur, studi kepustakaan dan kuesioner. Data dianalisis dengan regrasi linear berganda bertingkat dengan uji path analisis. Berdasarkan hasil analisis data serta uraian pembahasan menunjukkan bahwa variabel rotasi kerja memiliki dampak positif dan signifikan terhadap motivasi kerja sedangkan rotasi kerja pada kinerja karyawan memiliki dampak positif meskipun tidak signifikan, rotasi kerja memiliki dampak yang positif dan signifikan terhadap kinerja karyawan melalui motivasi kerja.

Kata kunci: Rotasi Kerja, Motivasi Kerja, Kinerja Karyawan 


\section{PENDAHULUAN}

Perkembangan industri pariwisata yang begitu pesatnya perkembangannya, membuat persaingan bisnis semankin ketat, banyak perusahaan pariwisata terutama dibidang jasa mewajibkan karyawannya untuk meningkatkan keunggulannya di segala bidang guna mencapai tujuan perusahaan melalui kinerja yang maksimal. Hal yang harus diperhatikan oleh perusahaan tetutama dalam pelaksanaan suatu pekerjaan yaitu proses dalam mencapai target yang ditentukan, sesuai dengan standar kerja yang ditetapkan dan diinginkan oleh perusahaan. Industri jasa ini merambah ke berbagai lini yang

diantaranya jasa perhotelan, jasa pendidikan, jasa medis/kesehatan, jasa angkutan dan lain sebagaiknya. Industri jasa tersebut menuntut sumber daya yang tinggi guna memuaskan pelanggan yang menjadi syarat utamanya.

Hotel merupakan perusahaan yang menjual jasa selain dari produk, dalam pengelolaanya terutama bidan jasanya yang memerlukan kecakapan yang tinggi, karena cukup rumit dalam pengelolaanya, terkait dengan menyediakan berbagai macam fasilitas yang dapat digunakan ole pelanggannya selama 24 jam, selain itu terutama wisatawan yang melakukan perjalanan dengan tujuan mengunjungi tempat - tempat wisata, kebanyakan para wisatawan memerlukan tempat menginap, makan dan minuman serta hiburan. Maka dari itu persaingan industri jasa terutama di perhotelan memacu pihak manajemen untuk terus berusaha menemukan formula agar usahanya tetap berkembang, apa lagi setiap hotel di tuntut meningkatkan manajemen pelayanan, penghematan biaya tanpa harus mengurangi kualitas pelayanan sebagai daya saing yang kompetitif. Hal ini erat sekali kaitannya dengan produktifitas kerja perusahaan, guna menjamin kelangsungan hidup perusahaan, perlu adanya pengingkatan produktifitas secara terus-menerus dikembangkan. Dalam hal ini salah satu hotel yang ada di jember yaitu hotel Panorma dan hotel Asri diharapkan memiliki sumberdaya manusia yang berkualitas, karena dengan sumberdaya yang berkualitas akam membedakan dari satu hotel dengan hotel yang lainnya, di samping itu juga perlu adanya inovasi yang secara terus-menerus guna memenuhi keinginan dan kebutuhan pelanggan yang selalu berubah-ubah

Berhasil tidaknya subuah perusahaan tidak lepas dari hasil kerja yang dicapai oleh karyawannya dalam melaksanakan tugasnya sesuai dengan job description masing-masing karyawan. Salah satu faktor yang mempengaruhi sebuah kinerja diantaranya motivasi dan rotasi kerja.

Berdasarkan penelitian yang dilakukan Solikhah (2016), Putri (2013) dan Andriani (2013). Hasil penelitiannya menunjukkan bahwa rotasi kerja berpengaruh positif dan signifikan terhadap kinerja karyawan. Artinya ketika rotasi kerja meningkat maka kinerja karyawan juga akan mengalami peningkatan. Selain itu juga penelitian yang dilakukan Agus dan

Sutanto (2013) hasil penelitian menunjukkan bahwansannya motivasi kerja berpengaruh positif pada kinerja karyawan. Artinya ketika motivasi kerja meningkat maka kinerja karyawan juga akan mengalami peningkatan. Dan penelitian yang dilakukan Santoso dan Riyadi (2012)

hasil penelitian menunjukkan bahwansannya rotasi kerja berpengaruh positif pada kinerja karyawan. Artinya ketika rotasi kerja meningkat maka kinerja karyawan juga akan mengalami peningkatan

Kerangkan Pemikiran Penelitian ini dilakukan dengan suatu

kerangka pemikiran sebagaimana terlihat dalam gambar 1 


\section{Gambar 1 Kerangka Konsep}

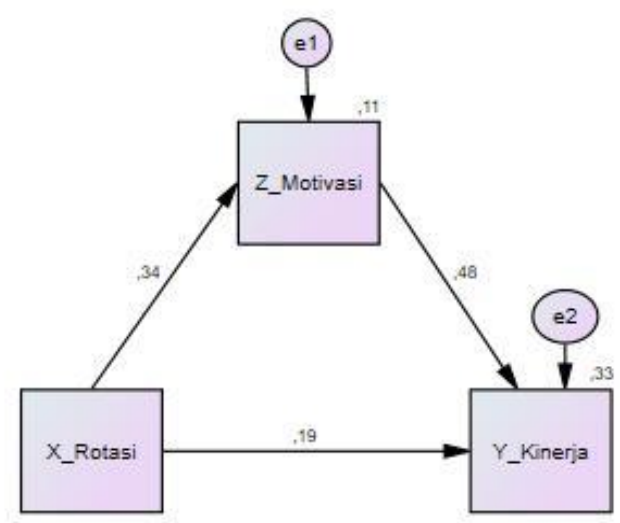

\section{Hipotesis}

Berdasarkan hasil penelitian sebelumnya dan kerangkan pemikiran, maka ditetapkan beberapa hipotesis penelitian, antara lain $\mathrm{H}_{1}$ : diduga terdapat pengaruh signifikan dan bersifat positif antara rotasi kerja dengan motivasi kerja; $\mathrm{H}_{2}$ : diduga terdapat pengaruh signifikan dan bersifat positif antara rotasi kerja dengan kinerja karyawan.; $\mathrm{H}_{3}$ : diduga terdapat pengaruh signifikan dan bersifat positif antara motivasi kerja dengan kinerja karyawan

\section{METODE PENELITIAN}

\section{Tahap penelitian}

Tahap kegiatan ini diawali dengan persiapan survei yaitu uji instrumen penelitian. Lalu setelah memperoleh instrumen yang valid dan reliabel dengan distribusi normal, maka tim surveior turun lapang untuk menggali informasi data primer dan sekunder tentunya setelah memperoleh perijinan dari pihak berwenang. Kusioner yang telah terisi rekaman data di lapangan selanjutnya diedit, koding dan ditabulasi untuk kemudian dianalisa menggunakan program aplikasi (software) pengolahan SPSS for windows. Selanjutnya tahap berikutnya adalah penyusunan draf laporan kemajuan dan laporan akhir berdasarkan hasil analisis

data. Setelah dilakukan kegiatan monitoring dan evaluasi oleh LPPM, maka penyusunan laporan akhir final dan publikasi ilmiah segera dilaksanakan. Hasil peyusunan kedua output atau luaran tersebut selanjutnya dikirim ke pihakpihak berwenang

\section{Populasi Dan Sampel Penelitian}

Poulasi dalam penelitian ini adalah karyawan hotel panorama dan hotel Asri.

Penelitian ini menggunakan Non Probability Sampling dengan teknik sampling jenuh (sensus). sampling jenuh atau definisi sampling jenuh adalah teknik penentuan sampel bila semua anggota populasi digunakan sebagai sebagai sampel. Hal ini sering dilakukan bila jumlah populasi relative kecil, kurang dari 30 orang, atau penelitian yang ingin membuat generalisasi dengan kesalahan yang sangat kecil

\section{Definisi Operasional Variabel Rotasi Kerja (X)}

Rotasi kerja yang diteliti dalam penelitian ini didefinisikan sebagai perubahan periodik pekerja dari satu tugas ke tugas yang lainnya. Untuk mengukur variabel rotasi pekerjaan digunakan tiga yang dikembangkan oleh Ortega (2001) dan Mangiapane (1988), yaitu : a.tambahan skill, b.tambahan pengetahuan, c.tingkat kejenuhan kerja, d. kerja, e.kebijakan 


\section{Definisi Operasional Variabel \\ Motivasi Kerja (Z)}

otivasi kerja didefinisikan sebagai dorongan yang datang dari dalam diri manusia yang mengaktifkan, menggerakkan serta mengarahkan perilaku untuk mencapai tujuan. Variabel motivasi kerja diukur dengan menggunakan enam indikator yang dikembangkan oleh Pareek (1985) dalam Mas'ud (2004) yang meliputi: a.prestasi kerja, b.pengaruh, c.pengendalian, d.ketergantungan, e.perluasan, f.afiliasi

\section{Definisi Operasional Variabel Kinerja Karyawan (Y)}

Kinerja pegawai adalah hasil yang telah dicapai dari yang telah dilakukan, dikerjakan seseorang dalam melaksanakan kerja atau tugas. Variabel kinerja pegawai dalam penelitian ini diukur oleh tujuh indikator yang dikembangkan oleh Suliman (2002) dan McNeese-Smith (1996) yaitu: a.kualitas hasil kerja, b.keuletan kerja, c.disiplin kerja, d.kerjasama antar rekan kerja, e.kepedulian akan keselamatan kerja, f.tingkat tanggung jawab atas hasil pekerjaan, g.kreativitas yang dimiliki

\section{Metode Mengumpulkan Data}

Penelitian ini menggunakan metode angket atau kuesioner Oleh karena itu wawancara merupakan sebuah set pertanyaan yang diberikan kepada responden terpilih tentang hal yang berkaitan dengan maksud penelitian (Nazir, 2003)

\section{Metode Analisis Data}

Metode analisis data dalam penelitian ini menggunakan analisis statistik deskriptif, uji validitas, uji reliabilitas, serta dengan menggunakan path analysis yang akan menggunakan SPSS for Windows Ver. 22.0.

Analisis deksriptif digunakan untuk memperoleh gambaran secara mendalam dan obyektif mengenai objek penelitian. Analisis deskriptif menggunakan alat ukur, yaitu mean. Analisis rata-rata/mean diguna- kan untuk mengetahui frekuensi rata-rata jawaban dari responden terhadap masingmasing pernyataan pada tiap total variabel maupun pada tiap dimensi dari variabel tersebut.
Uji validitas dalam penelitian ini dilakukan untuk menguji ketepatan item- item pernyataan kuesioner dalam mengukur variabel penelitian. Teknik yang digunakan adalah korelasi pearson product moment. Suatu item pernyataan dinyatakan valid jika korelasi product moment pearson menghasilkan nilai signifikansi $(\alpha)<0,05$ (Sugiyono, 2007).

Uji reliabilitas dalam penelitian ini dilakukan untuk menguji kehandalan kuesioner dalam mengukur variabel penelitian dengan menghasilkan pengukuran yang konsisten. Teknik yang digunakan adalah uji Cronbach's Alpha. Item-item pernyataan dalam angket dinyatakan reliabel jika nilai Cronbach's Al- pha > 0,6 (Ghozali, 2012).

Langkah selanjutnya yaitu path analysis, adalah pengujian validitas model. Sahih tidaknya suatu analisis bergantung pada terpenuhi atau tidaknya asumsi yang melandasinya. Asumsi yang melandasi path analysis adalah :

a. Didalam model path analysis, pengaruh antar variabel adalah linier dan aditif

b. Hanya model rekursif (system aliran kausal ke satu arah) dapat dipertimbangkan, sedangkan pada model yang bergantung kausal resiprokal tidak dapat dilakukan path analysis.

c. Variabel endogen minimal dalam skala ukur interval.

d. Observed variables diukur tanpa kesalahan (instrument pengukuran valid dan reliabel)

Model yang dianalisis dispesifikasikan (diidentifikasi) dengan benar berdasarkan teori-teori dan konsep- konsep yang relevan.

Responden penelitian ini adalah para karyawan hotel Asri dan hotel Panorama yang berjumlah 50 orang. Karakteristik responden dibedakan berdasarkan, jenis kelamin, usia, pendidikan, lama bekerja. Karakteristik responden digunakan peneliti dibuat untuk mempermudah dalam penilaian dan pengambilan kesimpulan. diketahui bahwa dari 50 orang responden, sebanyak $50 \%$ atau sebanyak 25 terdiri dari laki-laki dan $50 \%$ atau sebanyak 25 perempuan yang berarti bahwa jumlah responden laku-laki dan perempuan seimbang. 
Faktor usia responden berusia antara $<20$ tahun sebasar $14 \%$ atau sebanyak 7 orang, usia antara 21-30 tahun sebesar 68\% atau sebanyak 34 orang, usia antara 31-40 tahun sebesar $16 \%$ atau sebanyak 8 orang, usia antara 41-50 tahun sebesar 2\% atau sebanyak 1 orang, usia antara $>50$ tahun tidak ada. Dari tabel di atas juga dapat dilihat bahwa responden dengan usia yang paling banyak adalah yang berusia antara 21 - 30 tahun. responden yang berpendidikan SD yaitu sebanyak 0 orang atau $0 \%$, jumlah responden yang berpendidikan SMP yaitu sebanyak 0 orang atau $0 \%$, jumlah responden yang berpendidikan SMA yaitu sebanyak 40 orang atau $80 \%$ dari jumlah responden, jumlah responden yang pendidikan D3/S1 yaitu sebanyak 10 orang atau $20 \%$, sedangkan yang berpendidikan S2 dan S3 tidak ada. Dari tabel di atas juga dapat dilihat bahwa responden dengan berpendidikan SMA sebanyak 40 orang. responden yang bekerja diatas 10 tahun yaitu sebanyak 4 orang atau $8 \%$, jumlah responden yang bekerja 5 th -10 th yaitu sebanyak 18 orang atau $36 \%$, jumlah responden yang bekerja dibawah 5 th yaitu sebanyak 28 orang atau $56 \%$ dari jumlah responden. Dari tabel di atas juga dapat dilihat bahwa responden yang bekerja dibawah 5 th yang paling banyak sebanyak 28 orang

Tabel 1 Uji Validitas dan Reliabilitas

\begin{tabular}{|c|c|c|c|c|c|}
\hline & No & $\begin{array}{l}\text { Butir } \\
\text { Pernyataan }\end{array}$ & $\begin{array}{l}\text { Koefisien } \\
\text { Korelasi }\end{array}$ & $\begin{array}{l}\text { Koefisien } \\
\text { Alpha } \\
\text { Cronbach }\end{array}$ & Keterangan \\
\hline \multirow{4}{*}{$\begin{array}{l}\text { Rotasi } \\
\text { Kerja }\end{array}$} & 1 & Pertanyaan 1 & 0,366 & \multirow{4}{*}{0,027} & Valid \\
\hline & 2 & Pertanyaan 2 & 0,518 & & Valid \\
\hline & 3 & Pertanyaan 3 & 0,480 & & Valid \\
\hline & 4 & Pertanyaan 4 & 0,632 & & Valid \\
\hline \multirow{6}{*}{$\begin{array}{c}\text { Motivasi } \\
\text { Kerja }\end{array}$} & 1 & Pertanyaan 1 & 0,710 & \multirow{6}{*}{0,433} & Valid \\
\hline & 2 & Pertanyaan 2 & 0,573 & & Valid \\
\hline & 3 & Pertanyaan 3 & 0,543 & & Valid \\
\hline & 4 & Pertanyaan 4 & 0,489 & & Valid \\
\hline & 5 & Pertanyaan 5 & 0,485 & & Valid \\
\hline & 6 & Pertanyaan 6 & 0,369 & & Valid \\
\hline \multirow{6}{*}{$\begin{array}{c}\text { Kinerja } \\
\text { Karyawan }\end{array}$} & 1 & Pertanyaan 1 & 0,719 & \multirow{6}{*}{0,638} & Valid \\
\hline & 2 & Pertanyaan 2 & 0,634 & & Valid \\
\hline & 3 & Pertanyaan 3 & 0,515 & & Valid \\
\hline & 4 & Pertanyaan 4 & 0,730 & & Valid \\
\hline & 5 & Pertanyaan 5 & 0,719 & & Valid \\
\hline & 6 & Pertanyaan 6 & 0,467 & & Valid \\
\hline
\end{tabular}


Dari tabel 1 diatas, dapat dinyatakan bahwa seluruh butir pertanyaan variabel waktu luang pada $\alpha=0,05$ berstatus valid, sehingga keseluruhan skor indikatorindikator tersebut data memberikan representasi yang baik. Uji reliabilitas dalam penelitian ini dilakukan dengan Cronbach Alpha $(\alpha)$. Instrumen dikatakan reliable apabila memiliki nilai Cronbach Alpha $(\alpha)$ 0.2732. hasil reliabilitas disajikan pada tabel diatas.

Pada bagian ini menguraikan tiaptiap jalur pada bagian model dengan menggunakan analisis jalur (Path Analysis). Tiap-tiap jalur yang diuji menunjukkan pengaruh langsung dan tidak langsung rotasi pekerjaan (X), motivasi kerja (Z), kinerja karyawan (Y) di hotel Asri dan hotel Panorama. Dengan mengetahui signifikan atau tidaknya tiaptiap jalur tersebut akan menjawab apakah hipotesis yang diajukan diterima atau ditolak. Masing-masing jalur yang diuji mewakili hipotesis yang ada dalam penelitian ini. Nilai koefisien jalur dapat dilihat pada tabel berikut:

Tabel 2 Nilai Koefisien Jalur Pengaruh Langsung

\begin{tabular}{|c|c|c|c|c|c|}
\hline & Estimate & S.E. & C.R. & $\mathrm{P}$ & Ket \\
\hline Z_Motivasi <--- X_Rotasi & ,336 &, 169 & 2,499 &, 012 & Signifikan \\
\hline Y_Kinerja <--- X_Rotasi & 192 & ,124 & 1,549 & 121 & Tidak Signifikan \\
\hline Y_Kinerja <--- Z_Motivasi & ,485 & ,099 & 3,914 & $* * *$ & Signifikan \\
\hline
\end{tabular}

Pengujian variabel rotasi pekerjaan $(\mathrm{X})$ terhadap motivasi kerja $(\mathrm{Z})$ diperoleh nilai beta $(\beta)$ sebesar 0,336 dengan $\rho$-value sebesar 0,012. Karena nilai $\rho$-value lebih kecil dari pada $\alpha(0,012<0,05)$ maka H0 ditolak dengan demikian ada pengaruh positif secara signifikan rotasi pekerjaan (X2) terhadap motivasi kerja

(Z).

Pengujian variabel rotasi pekerjaan (X) terhadap kinerja karyawan (Y) diperoleh nilai beta $(\beta)$ sebesar 0,192 dengan $\rho$-value sebesar 0,121 . Karena nilai $\rho$-value lebih besar dari pada $\alpha$ $(0,121<0,05)$ maka H0 diterima dengan demikian ada pengaruh tetapi tidak signifikan rotasi pekerjaan (X) terhadap kinerja karyawan (Y).

Pengujian variabel motivasi kerja

(Z) terhadap kinerja karyawan (Y) diperoleh nilai beta $(\beta)$ sebesar 0,485 dengan $\rho$-value sebesar 0,000. Karena nilai $\rho$-value lebih kecil dari pada $\alpha$ $(0,000<0,05)$ maka H0 di tolak dengan demikian ada pengaruh secara motivasi kerja (Z) terhadap kinerja karyawan (Y).

Tabel 3 Pengujian Perngaruh Variabel Intervening

\begin{tabular}{|l|l|}
\hline & Rotasi Pekerjaan - Kinerja karyawan \\
\hline Pengaruh Langsung & $=0.19$ \\
\hline Pengaruh Tidak Langsung & $=0.34$ x 0.48 \\
& $=0.163$ \\
\hline Pengaruh Total & $=0.19+0.163$ \\
& $=0.353$ \\
\hline \multirow{5}{*}{ Kesimpulan } & $\begin{array}{l}\text { Pengaruh langsung > Pengaruh tidak langsung } \\
\text { : Variabel variabel rotasi pekerjaan dan } \\
\text { motivasi kerja untuk meningkatkan kinerja } \\
\text { karyawan }\end{array}$ \\
\hline
\end{tabular}


Berdasarkan Tabel 3, diketahui bahwa pengaruh rotasi pekerjaan terhadap kinerja karyawan masing-masing memiliki pengaruh langsung yang sama besar dari pengaruh tidak langsungnya, artinya motivasi kerja karyawan bersinergi dengan variabel rotasi pekerjaan dalam mengoptimalkan kinerja karyawan di hotel Asri dan hotel Panorama. Hal tersebut dikarenakan rotasi pekerjaan yang ada di hotel Asri dan hotel Panorama memiliki dampak positip kepada kinerja karyawan, dengan adanya rotasi pekerjaan yang secara berkala membuat karyawan memiliki pengalaman kerja yang lebih dan pengetahuan lebih pula. Maka dari itu rotasi pekerjaan penting guna meningkatkan serta menaikkan kualitas kerja karyawan.

Koefisien determinasi merupakan besaran yang menunjukkan besarnya variasi variabel dependen yang dapat dijelaskan oleh variabel independennya. Dengan kata lain, koefisien determinasi ini digunakan untuk mengukur seberapa jauh variabel-variabel bebas dalam menerangkan variabel terikatnya. Nilai koefisien determinasi pada penelitian ini adalah sebagai berikut:

\section{Tabel 4 Koefisien Determinasi , X, Terhadap Z Model Summary ${ }^{b}$

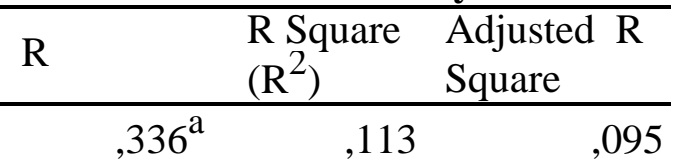

Sumber: Data Diolah Lampiran 3 hal 27

Pengaruh $\epsilon 1$ (variabel selain , X, terhadap Z)

$$
\begin{aligned}
& =\sqrt{ } 1-\mathrm{R}^{2} \\
& =\sqrt{ } 1-0,095^{2} \\
& =\sqrt{ } 1-0,009 \\
& =0,009 \text { atau } 0,9 \%
\end{aligned}
$$

Tabel 5 Koefisien Determinasi, X, Z, Terhadap Y

Model Summary ${ }^{b}$

\begin{tabular}{lrrr}
\hline $\mathrm{R}$ & \multicolumn{2}{l}{$\begin{array}{l}\text { R Square } \\
\left(\mathrm{R}^{2}\right)\end{array}$} & $\begin{array}{l}\text { Adjusted R } \\
\text { Square }\end{array}$ \\
\hline, $578^{\mathrm{a}}$ &, 334 &, 306 \\
\hline
\end{tabular}

Sumber: Data Diolah Lampiran 3 hal 27

Pengaruh $\epsilon 1$ (variabel selain , $\mathrm{X}$, terhadap Z)

$$
\begin{aligned}
& =\sqrt{ } 1-\mathrm{R}^{2} \\
& =\sqrt{ } 1-0,306^{2} \\
& =\sqrt{ } 1-0,094 \\
& =0,094 \text { atau } 9,4 \%
\end{aligned}
$$

Koefisien determinasi Total : $R_{m}^{2}=1-P_{e 1}^{2} P_{e 2}^{2}$

$$
\begin{aligned}
R_{m}^{2} & =1-(0,009)^{2} \cdot(0,094)^{2} \\
& =1-(0,000081.0,0088) \\
& =1-0,0000007 \\
& =0,9999993
\end{aligned}
$$

Hasil perhitungan path analysis dapat diketahui bahwa koefisien determinasi R2 total diperoleh nilai sebesar 0,9999993. Hal ini berarti 99,99993\% variasi variabel rotasi pekerjaan (X), motivasi kerja (Z), kinerja karyawan (Y), sedangkan sisanya sebesar $0,00007 \%$ 
diterangkan oleh variabel lain dan error yang tidak dijelaskan dalam penelitian ini.

\section{KESIMPULAN}

Berdasarkan hasil pembahasan tentang dampak rotasi kerja pada motivasi dan kinerja karyawan di hotel panorama dan hotel Asri jember dari hasil analisis kuesioner 50 responden diperoleh kesimpulan sebagai berikut :

1. Dampak dengan adanya rotasi kerja terhadap motivasi kerja karyawa menunjukkan bahwan ada pengaruh positif dan signifikan di hotel Asri dan hotel Panorama, terbukti setelah dilakukan analisa pernyataan tersebut Ha diterima yang berarti secara parsial variabel rotasi kerja berpengaruh signifikan terhadap karyawan hotel Asri dan hotel Panorama. thitung positif, maka jika ada peningkatan pada variabel rotasi kerja maka akan meningkatkan motivasi kerja karyawan.

2. Dampak dengan adanya rotasi kerja terhadap kinerja karyawan hotel Asri dan hotel Panorama, menunjukkan bahwa ada pengaruh positif dan signifikan, terbukti setelah dilakukan analisis pernyataan tersebut Ho diterima berarti secara parsial variabel motivasi kerja berpengaruh positif tetapi tidak signifikan terhadap karyawan hotel Asri dan hotel Panorama. thitung positif, maka jika ada peningkatan pada variabel rotasi kerja maka akan belum tentu meningkat kinerja karyawan hotel Asri dan hotel Panorama.

3. Dampak dengan adanya rotasi kerja terhadap kinerja karyawan melalui motivasi kerja, menunjukkan bahwa ada pengaruh positif dan signifikan, terbukti setelah di lakukan analisis peryataan tersbut Ha diterima berarti secara parsial variabel motivasi kerja berpengaruhsignifikanterhadap kinerja karyawan hotel Asri dan hotel Panorama . thitung positif, maka jika ada peningkatan pada variabel motivasi kerja maka akan meningkatkan kineja karyawan hotel Asri dan hotel Panorama

\section{DAFTAR REFERESI}

Agusta, Leonando, dan Madiono Sutanto. 2013. "Pengaruh Pelatihan Dan Motivasi Kerja Terhadap Kinerja Karyawan Cv Haragon Surabaya." jurnal AGORA (Program Studi Manajemen) 1 (3): 1.

Andriani, Novi. 2013. Pekerjaan Terhadap Kinerja Karyawan PT. Kereta Api Indonesia (Persero) Daerah Operasi IX Jember. Fakultas Ekonomi (Jurusan Akuntansi), Universitas Jember, Jember: Fakultas Ekonomi .

Arikunto, Suharsimi. 2010. Prosedur Penelitian, Suatu Pendekatan Praktik. 14. Jakarta: Rineka Cipta.

Befort, N, dan K Hattrup. 2003. "Valuing Task and Contextual Performance: Experience, Job Roles, and Ratings of The Importance of Job

Behaviors." Applied H.R.M. Research 8: 1.

Borman, W C, dan S J Motowidlo. 1993. Expanding The Criterion Domain to Include Elements of Contextual Performance. San Francisco : Jossey-Bass.

Brahmasari, I A, dan A Suprayetno. 2008. "Pengaruh Motivasi Kerja, Kepemimpinan dan Budaya organisasi terhadap Kepuasan Kerja Karyawan serta Dampaknya pada Kinerja Perusahaan (Studi kasus pada PT. Pei Hai International

Wiratama Indonesia." Jurnal Manajemen dan Kewirausahaan 10: 2 . 
Campion, Michael A, Lisa Cheraskin, dan Michael J Stevens. 1994. "CareerRelated Antecedents and Outcomes Of Job Rotation." Academy of Management Journal 37: 6.

Chen, Y F. 2009. "Job Stress and Performance: A Study of Police Officers in Central Taiwan." Social Behavior and Personality 37: 10.

Ferdinand, Augusty. 2006. Metode Penelitian Manajemen: Pedoman Penelitian untuk skripsi, Tesis dan Disertai Ilmu Manajemen. kedua. Semarang: BP Undip.

Ghozali, Imam. 2005. Aplikasi Analisis Multivariate dengan SPSS. Semarang: Badan Penerbit UNDIP.

Gibson, Ivanicevich, dan Donnely. 1989. Organisasi: Perilaku, Struktur, dan. Proses. Jakarta: Erlangga.

Gitosudarmo, Indriyo, dan I Nyoman Sudita. 2000. Perilaku Keorganisasian. 1. Yogyakarta: Erlangga.

Gujarati, Damodar. 2013. Ekonometri Dasar. Dialihbahasakan oleh Sumarno Zain. Jakarta: Erlangga.

Hasibuan, H Malayu SP. 2003. Manajemen Sumber Daya Manusia. Jakarta : Bumi Aksara.

Hsien Ho, Wen, Ching Sheng Chang, YingLing Shih, dan Rong-Da Liang. 2005. "Effects of Job Rotation and Role Stress among Nurses on Job Satisfaction and Organizational Commitment." BMC Health Services Research 1.

Indriantoro, dan Supomo. 1999. Metodologi Penelitian Bisnis untuk Akuntansi dan Manajemen. satu. Yogyakarta: BPFE Yogyakarta.

Jackson, John H, dan Robert L Mathis. 2009. Manajemen Sumber Daya Manusia. 10. Jakarta: Salemba Empat.
Kaymaz, Kurtulus. 2010. "The Effect of Job Rotation Practise on Motivation : A Research on Managers in the Automative Organizations. Isletme ve Ekonomi Arastirmlan Dergiri,." Business and Economics Research 1: 3.

Kurniawan, Albert. 2009. Belajar Mudah SPSS Untuk Pemula. Yogyakarta: Mediakom.

Mangiapane, Adele. 1988. "Empowering People To Improve a Process." Manufacturing Systems 6: 1.

Mangkunegara, Anwar Prabu. 2000. Manajemen Sumber Daya Manusia Perusahaan. Bandung : Remaja Rosdakarya.

Mangkunegara, Anwar Prabu. 2002. Manajemen Sumber Daya Manusia. Bandung: Remaja Rosda Karya.

Mas'ud, Fuad. 2004. Survai Diagnosis Organisasional, konsep dan Aplikasi. Semarang: BP Undip.

McKenna, Eugene, dan Nic Beech. 2000. The Essence of Human Resource Management. Yogyakarta : ANDI.

McNeese-Smith, Donna. 1996. "Increasing Employee Productivity, Job Satisfaction and Organizational Commitment." Hospital \& Health Services Administration 41: 1.

Meyer, Thomas E, Becker, dan Christian Vandenberghe. 2004. "Employee Commitment and Motivation: A Conceptual Analysis and Integrative Model." Journal of Applied Psychology 86 (6): 9911007.

Motowidlo, S J, W C Borman, dan M J Schmit. 1997. "A Theory of Individual Differences in Task and Contextual Performance." Human Performance 10.

Nazir, Moch. 2003. Metode Penelitian. Jakarta: Salemba Empat. 
Ortega, Jaime. 2001. "Job Rotation as a Learning Mechanism." Management Science 47: 10-25.

Pareek, Udai. 1985. Mendayagunakan Peran - Peran keorganisasi. Jakarta: Pustaka Binaman Persindo.

Putri, Putu Ayu Cintya Permata. 2013. Analisis Pengaruh Rotasi Pekerjaan Dan Pengembangan Karir Terhadap Motivasi Dan Kinerja Karyawan Pada Pt.Bank Jatim Cabang Jember. Fakultas Ekonomi (Jurusan Akuntansi), Universitas Jember., jember: Fakultas Ekonomi.

Rivai, Veithzal, dan Ella Jauvani Sagala . 2009. Manajemen Sumber Daya Manusia untuk Perusahaan. Jakarta: Raja Grafindo Persada.

Robbins , SP, dan Judge. 2008. Perilaku Organisasi. Jakarta: Salemba Empat.

Robbins, Stephen P. 2003. Perilaku Organisasi. Jakarta : Prenhallindo.

-. 1996. Perilaku Organisasi, Konsep, Kontroversi dan Aplikasi. 6. Dialihbahasakan oleh Hadyana Pujaatmaka. Jakarta: Bhuana Ilmu Populer.

Santoso, Budi, dan Agung Riyardi. 2012. "rotasi, mutasi dan promosi karyawan di kantor pelayanan pajak Pratama Klaten." Jurnal Ekonomi \& Manajemen Bisnis 13 (1): 1-9.
Siagian, Sondang. 2009. Manajemen Sumber Daya Manusia. Jakarta : Bumi Aksara.

Simamora, Henry. 1997. Manajemen Sumber Daya Manusia. 2. Yogyakarta: Bagian Penerbitan Sekolah Tinggi Ilmu Ekonomi YKPN.

Solikhah, Siti. 2016. "Analisis Pengaruh Rotasi Kerja, Motivasi Kerja." Jurnal Muqtasid 7 (2): 23-49.

Sugiyono. 2012. Memahami Penelitian Kualitatif. Bandung: Alfabeta.

-. 2015. Metode Penelitian Kuantitatif Kualitatif $R \& B$. Bandung: Aflabeta.

-. 2007. Metodologi Penelitian Bisnis. Jakarta: Gramedia.

Suliman, Abubakar MT. 2002. "Is It A Really a Mediating Construct?" Journal of Management Development 21: 1.

Sundin, Elisabeth. 2001. "Grenderdetermined Jobs and JobrotationProblems and Possibilities." The Service Industries Journal 21: 3.

Whitmore, J. 2002. Coaching for performance, Seni Mengarahkan untuk Mendongkrak Kinerja. Gramedia: Jakarta.

Wijaya, Tony. 2010. Analisis Multivariat. Yogyakarta: Universitas Atma Jaya.

Wijono, Sutarto. 2007. Motivasi Kerja. Salatiga : Widya Sari. 